\title{
WANITA HAMIL DAN MENYUSUI YANG MENINGGALKAN PUASA RAMADHAN DALAM PERSPEKTIF HANAFIYAH DAN SYAFI'IYAH
}

\author{
Amri Effendi \\ Institut Agama Islam Negeri Batusangkar \\ e-mail: amrieffendi@iainbatusangkar.ac.id
}

\begin{abstract}
Fasting is one of the pillars of Islam that must be shown by someone who has fulfilled certain requirements. Islamic scholars agree that the fasting of Ramadan must be carried out by every adult, resourceful, Muqim (in bis place of residence), and healthy as long as he/she has not been a barrier to fasting, such as menstruation and Nifas for women. The purpose of this discussion is to explain the perspective of Hanafiyah and Shafi'yah against pregnant and nursing women who avoided the fasting of Ramadan. This type of research is a library research (literature research). The results shows that the perspective of Hanafiyah Ulama and Syafi'iyah Ulama about the consequences of the law on pregnant and nursing women who avoided the Ramadan fasting due to fear of safety of herself and her son there are differences of opinion. There were distinction opinion in establishing mandatory fidyah as a result of its law while in concerning fasts agreed upon by both.
\end{abstract}

Kata kunci: Wanita hamil, menyusui, puasa, Hanafiyah, Syafi'iyyah

\section{PENDAHULUAN}

$\mathcal{A}_{\mathrm{jin}}^{11}$ lah SWT menciptakan manusia dan jin di bumi untuk menyembah, dan beribadah kepada-Nya, karena itu manusia harus tunduk dan patuh kepada Khaliq-Nya sebagai penciptanya. Tujuan ini dijelaskan oleh Allah dalam firmanNya:

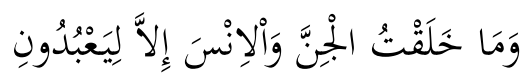

"Dan tidak aku ciptakan jin dan manusia melainkan supaya mereka menyembah-Ku". (Q.S. Adz-Dzariyat [51]: 56)

Ibadah yang dilakukan oleh seorang hamba secara umum terbagi dua. Pertama, ibadah secara vertikal yaitu ibadah yang menyangkut hubungan langsung dengan Allah, seperti shalat, puasa Ramadhan, haji, dan lain-lainnya.
Kedua, ibadah secara horizontal, yaitu ibadah yang mengatur hubungan manusia dengan manusia, seperti jual beli.

Puasa sebagai salah satu jenis ibadah yang langsung berhubungan dengan Allah memiliki kedudukan penting dalam membentuk manusia menjadi hamba yang muttaqin. Hal ini telah dijelaskan oleh Allah dalam firman-Nya:

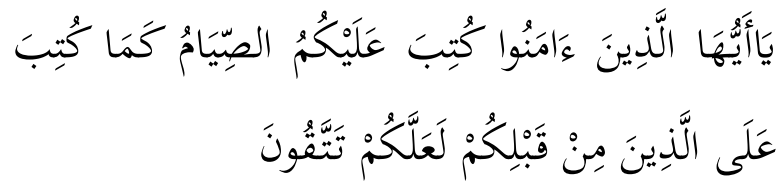

"Hai orang-orang yang beriman diwajibkan atas kamu berpuasa sebagaimana diwajibkan atas orang-orang sebelum kamu agar kamu bertaqwa". (Q.S. Al-Baqarah [2]: 183) 
Berdasarkan ayat ini dapat kita pahami bahwasanya hukum menjalankan ibadah puasa bukanlah hal yang baru dibuat setelah Nabi Muhammad SAW, melainkan sudah menjadi kewajiban bagi umat terdahulu.

Puasa merupakan salah satu dari rukun Islam yang wajib ditunaikan seseorang yang sudah memenuhi beberapa persyaratan tertentu. Ulama sepakat menyatakan bahwa puasa Ramadhan wajib dilaksanakan oleh setiap orang Islam yang telah dewasa, berakal, muqim (ada di tempat kediamannya), dan sehat selama dalam dirinya tidak ada yang menjadi penghalang untuk berpuasa, seperti menstruasi, nifas bagi wanita (Qardhawi, 1997: 15).

Persyaratan-persyaratan yang dikemukakan oleh ulama fikih tadi memberikan indikasi bahwa orang kafir tidak disyaratkan untuk melakukan puasa, karena mereka tidak sah melakukan ibadat. Orang murtad juga tidak disyaratkan untuk puasa, tetapi bila ia masuk Islam kembali ia wajib mengqadha puasa yang tinggal selama masa murtadnya. Demikian juga terhadap orang yang bepergian (musafir) dan orang sakit dibolehkan untuk tidak berpuasa bila ia tidak sanggup untuk berpuasa karena perjalanannya atau rasa sakit yang dideritanya. Sebagaimana Allah Swt berfirman:

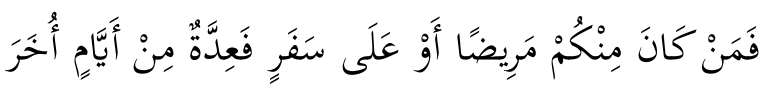

"Maka barang siapa di antara kamu sakit atau bepergian, maka (wajib baginya berpuasa) sebanyak hari yang ditinggalkan itu pada hari-hari yang lain". (Q.S. AlBaqarah [2]: 184)
Dalam keadaan biasa tidak sulit melaksanakan puasa dan tidak mengganggu fisik. Namun dalam keadaan tertentu, bagi orang tertentu melakukan puasa itu termasuk hal yang sulit dan dapat membahayakan. Oleh karena itu, Allah memberikan keringanan kepada orang tertentu itu untuk tidak berpuasa bulan Ramadhan. Adapun orang-orang yang mendapat keringanan melakukan puasa itu dan tindakan lanjutan yang harus dilakukannya, (Syarifuddin, 2003: 57), hal ini disebutkan Allah dalam dalam firman-Nya:

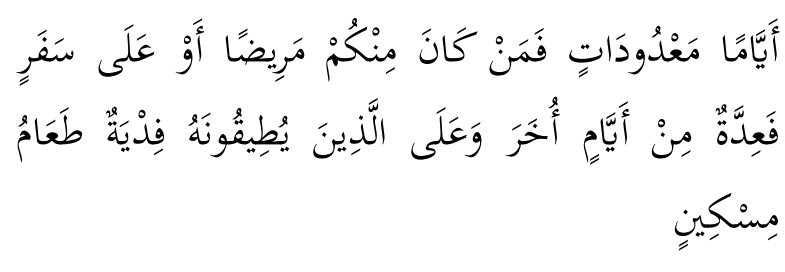

"(yaitu) dalam beberapa hari yang tertentu. Maka barangsiapa diantara kamu ada yang sakit atau dalam perjalanan (lalu ia berbuka), maka (wajiblah baginya berpuasa) sebanyak hari yang ditinggalkan itu pada hari-hari yang lain. Dan wajib bagi orangorang yang berat menjalankannya (jika mereka tidak berpuasa) membayar fidyah, (yaitu): memberi makan seorang miskin". (Q.S Al-Baqarah [2]: 184)

Dari ayat tersebut maka orang yang mendapatkan keringanan meninggalkan puasa Ramadhan itu adalah: (Syarifuddin, 2003: 58)

1. Orang sakit yang jika ia tetap berpuasa, penyakitnya akan bertambah atau lambat sembuhnya. Kewajiban orang ini mengqadha puasanya dari hari lain sebanyak yang ditinggalkannya.

2. Orang yang dalam perjalanan yang mengalami kesulitan bila berpuasa dalam arti dapat mengganggu kelancaran 
pekerjaannya. Kewajiban orang ini adalah mengqadha puasanya di hari-hari lain setelah ia berada ditempatnya.

3. Orang yang berat baginya melakukan puasa karena ketidakmampuan fisiknya. Keadaan begini berlaku dalam waktu yang lama sehingga tidak mungkin melaksanakan puasa dalam waktu dan keadaan apapun. Kewajiban orang ini hanyalah membayar fidyah dalam bentuk memberi makanan seorang miskin untuk setiap hari puasa yang tidak dilakukannya. Hal ini dikuatkan oleh hadis nabi dari Ibnu Abbas menurut riwayat Dar al-Quthni dan Hakim yang mengatakan:

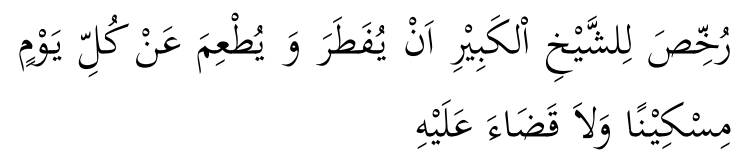

"Diberi keringanan orang tua renta untuk berbuka dan memberi makan seorang miskin untuk setiap harinya; dan tidak ada kewajiban qadha atasnya".

Allah juga memberikan keringanan kepada orang yang tidak mampu atau merasa berat untuk menunaikan ibadah puasa Ramadhan, maksudnya Allah memberikan rukhsah bagi orang yang tidak mempunyai kekuatan lahir dan batin dalam melakukan ibadah puasa Ramadhan yaitu wanita hamil dan menyusui.

Dalam hal ini terdapat perbedaan pendapat di kalangan para ulama fuqaha' terhadap kewajiban yang harus mereka bayarkan, sebagian ulama berpendapat bahwa orang-orang yang mendapatkan wanita hamil dan menyusui bila meninggalkan puasa maka kepada mereka diwajibkan meng-qadha puasanya saja. Sedangkan ulama lain berpendapat mereka hanya wajib meng-qadha puasanya sekaligus bayar fidyah kepada orangorang miskin.

Perbedaan pendapat tersebut terdapat pada di kalangan ulama Syafi'iyah dan ulama Hanafiyah. Menurut pandangan ulama Hanafiyah bahwa wanita hamil dan menyusui bila ia meninggalkan puasa Ramadhan maka ia wajib meng-Qadha puasanya tanpa wajib membayar fidyah. Sebagaimana juga diwajibkan meng-qadha puasa bagi wanita haid, nifas, dan seseorang yang dalam perjalanan (musafir). Karena orang hamil dan menyusui ditempatkan pada hukum orang sakit. Maka ia hanya wajib mengqadha puasa saja. Di samping ia berbuka di sebab 'uzur juga diumpamakan statusnya dengan orang tua lanjut usia (Al-'Aini, n.d: 293).

Pandangan ulama Syafi'iyah berpendapat bahwa wanita hamil dan menyusui bila ia takut atas dirinya dan anaknya lalu ia meninggalkan puasa Ramadhan maka ia wajib meng-qadha puasa tersebut serta membayar fidyah. Karena ia tidak bisa digolongkan kepada orang yang sakit (Al-Suyuthi, 1930: 266).

Pandangan Hanafiyah tentang kewajiban yang harus dibayar oleh wanita hamil dan menyusui yang meninggalkan puasa Ramadhannya ini juga tercantum dalam kitab al-Banaayah Fii Syarhi alHidayah, karangan Abi Muhammad Mahmud ibn Ahmad al-'Aini sebagai berikut: (Al-'Aini, n.d: 694).

1. Pandangan Hanafiyah

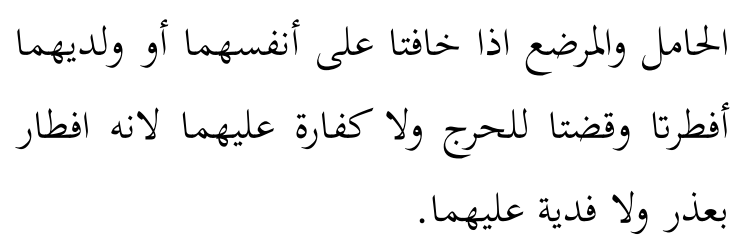


"Wanita hamil dan menyusui apabila ia takut atas dirinya atau anaknya maka boleh berbuka (meninggalkan puasa) dan meng-Qadha, (karena merasa berat). Dan tidak wajib atas keduanya membayar kafarat dan fidyah, karena ia berbuka dengan sebab uzur ".

2. Pandangan Syafi'iyah

Pandangan ini terdapat dalam kitab Al-Mughni 'Ala Mukhtashar alKharaqi karangan Abi Muhammad 'Abdullah bin Ahmad bin Muhammad Qudamah al-Muqaddasy:

(Al-

Muqaddasy, n.d: 99-100)

$$
\text { عليهما القضاء واطعام مسكين عن كل يلم يوم انلى ولديهما افطرتا و }
$$

"Wanita hamil dan menyusui apabila ia takut atas anaknya maka ia boleh berbuka dan wajib meng-Qadha sekaligus memberi makan orang miskin tiap-hari (ia tidak puasa)".

Bertitik tolak dari perbedaan pendapat Hanafiyah dan Syafi'iyah di atas, maka penulis ingin meneliti lebih dalam tentang kewajiban yang harus dipenuhi oleh "Wanita Hamil dan Menyusui yang Meninggalkan Puasa Ramadhan dalam Perspektif Hanafiyah dan Syafi'iyah".

\section{METODE PENELITIAN}

Jenis penelitian ini adalah library research dengan pendekatan kualitatif deskriptif. Penelitian dilakukan dengan menelaah buku-buku atau sumber lainnya yang relevan dengan pembahasan. Penggunaan pendekatan deskriptif dimaksudkan untuk menggambarkan informasi yang diteliti secara apa adanya untuk memaparkan fakta-fakta, informasi, atau data kejadiankejadian secara sistematis dan akurat.

\section{PEMBAHASAN}

\section{Pengertian Puasa dan Dasar Hukum Wajib Puasa}

\section{Pengertian Puasa}

Secara umum ulama sepakat mengatakan bahwa puasa adalah terjemahan dari bahasa Arab shaum dan shiyam yang berarti menahan dari sesuatu (Yunus, 1989: 224). Menahan dari sesuatu tersebut mencakup menahan dari makan, menahan dari minum, dan menahan dari jima' dari waktu subuh sampai terbenam matahari (Nizam, n.d: 214).

Adapun menurut istilah syar'i menurut ulama Hanafiyah dan Hanabilah, puasa adalah menahan dari hal-hal yang membatalkan dari terbit fajar sampai terbenam matahari dengan memenuhi syarat-syarat tertentu. Sementara menurut ulama Syafi'iyah dan ulama Malikiyah dalam istilah syar'i puasa adalah menahan dari hal-hal yang membatalkan dari terbit fajar sampai terbenam matahari dengan memenuhi syarat-syarat tertentu, serta dilengkapi dengan niat (Al-Jaziri, n.d: 541).

Perbedaan defenisi menurut istilah tersebut karena niat merupakan syarat dari puasa menurut ulama Hanafiyah dan Hanabilah sementara menurut ulama Syafi'iyah dan ulama Malikiyah niat merupakan rukun dari puasa. Kendatipun terjadi perbedaan pendapat di lingkungan ulama dalam memberikan defenisi puasa menurut syar'i tetapi mendudukan posisi niat dalam puasa namun mayoritas ulama sepakat mengatakan bahwa niat merupakan syarat sahnya melaksanakan 
puasa, jadi kalau seandainya seseorang melaksanakan puasa tanpa dibarengi niat maka secara otomatis puasanya tidak sah atau batal.

Dari keterangan di atas pada hakikatnya ulama sepakat mengatakan bahwa puasa itu adalah menahan diri dari segala hal yang membatalkan, mulai dari terbit fajar sampai terbenam matahari. Lalu jika dikaitkan dengan Ramadhan maka berarti puasa itu dilaksanakan pada bulan Ramadhan sebagai kewajiban yang mesti dilakukan oleh orang-orang yang beriman.

Dengan demikian ulama fikih sepakat berpendapat bahwa defenisi puasa adalah menahan dari segala hal yang membatalkan puasa mulai dari terbit fajar sampai terbenam matahari.

\section{Dasar Hukum Wajib Puasa Ramadhan}

Puasa ramadhan itu hukumnya wajib berdasarkan al-Qur'an, al-Sunnah, dan ijma' (kesepakatan ulama). Adapun dalil-dalilnya adalah sebagai berikut:

1. Al-Qur'an

$$
\text { Sebagaimana Allah Swt }
$$
berfirman:

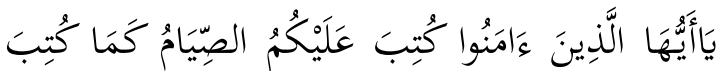

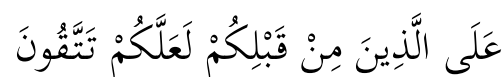

"Hai orang-orang yang beriman, diwajibkan atas kamu berpuasa sebagaimana diwajibkan atas orangorang sebelum kamu agar kamu bertaqwa". (Q.S. Al-Baqarah [2]: 183)

Selanjutnya terdapat dalam firman Allah Swt:

$$
\text { فَمَنْ شَهِدَ مِنْكُمُ الشَّهُهْ فَلْيَصُمْهُ }
$$

"Karena itu, barang siapa di antara kamu hadir di bulan itu, maka hendaklah ia berpuasa pada bulan itu". (Q.S. AlBaqarah [2]: 185)

2. Al-Sunnah

$$
\begin{aligned}
& \text { حدثنا عبد الله بن موسى قال : اخبرناحنظلة بن } \\
& \text { ابى سفيان عن عكرمة بن خالد عن ابن عمر قال: } \\
& \text { قال رسول الله صلى الله عليه وسلم بني الاسلام } \\
& \text { على خمس : شهادة ان لااله الاالله وان محمدا } \\
& \text { رسول الله واقام الصلاة وايتاء الزكاة والحج والصوم } \\
& \text { رمضان. (رواه البخاري) }
\end{aligned}
$$

Abdullah bin Musa menceritakan pada kami ia berkata: " telah mengkhabarkan pada kami oleh Hanzhalah ibn Abi Sufyan dari 'Ikrimah ibn Khalid dari Ibn Umar ia berkata : Bersabda Rasulullah $S A W$ : Islam didirikan atas lima : mengaku bahwa tiada Tuhan selain Allah dan bahwa Muhammad utusan Allah, mendirikan shalat, membayar zakat, haji, dan puasa pada bulan Ramadhan (HR. Bukhari) (AlBukhari, 1981: 81).

Dalam hadis lain Nabi bersabda:

عن ابي هريرة رضى الله عنه يقول : قال رسول الله صلى الله عليه وسلم : صوموا لرؤيته وافطروا ارؤيته فان غبي عليكم فأكملوا عدة شعبان ثلاثين. (رواه

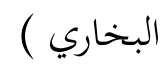

Dari Abi Hurairah r.a ia berkata: "Bersabda Rasulullah SAW: berpuasalah kamu karena melihat bulan dan berbukalah kamu karena melihat bulan. Apabila hilang bulan itu dari penglihatanmu hendaklah kamu 
sempurnakan bilangan bulan Sya'ban tiga puluh hari" (HR.Bukhari) (AlBukhari, 1981: 9-10).

\section{Ijma' Ulama}

Para ulama dari berbagai mazhab dan aliran di segenap penjuru dunia ini berpendapat bahwa hukum melaksanakan ibadah puasa Ramadhan adalah wajib dan merupakan fardhu 'ain bagi orangorang yang beriman yang memenuhi persyaratan. Kewajiban melaksanakan ibadah puasa Ramadhan merupakan kewajiban yang tidak bisa ditawartawar hukumnya karena didasarkan kepada dalil-dalil yang mutawatir serta tidak diragukan lagi keshahihannya.

\section{Syarat-Syarat Wajib Puasa dan Rukun Puasa}

\section{Syarat-Syarat Wajib Puasa}

Ibadah puasa Ramadhan diwajibkan kepada orang-orang yang memenuhi syaratsyarat yang tertentu. Para ulama di kalangan Hanafiyah dan Syafi'iyah ada yang sepakat dalam menentukan syaratsyarat wajib puasa Ramadhan dan ada yang perbedaan pendapat. Adapun yang mereka disepakati adalah sebagai berikut:

1. Islam, orang kafir tidak wajib puasa karena puasa tidak sah dilakukan kecuali telah masuk ke agama Islam. Kemudian jika orang kafir itu masuk Islam pada bulan Ramadhan, maka ia wajib berpuasa selama hari-hari yang tinggal pada bulan itu, dan tanpa diwajibkan mengqhada atau mengganti puasa pada hari-hari sebelumnya, inilah pendapat yang disepakati. (AsSyarbaini, n.d: 432)

2. Berakal, puasa itu tidak wajib bagi anak-anak, orang mabuk dan orang gila, namun bila hilang kehidupan akal itu terjadi karena kesengajaannya sendiri, maka ia wajib mengqhadanya setelah sembuh. Demikian pula wajib mengqhada bila ia mabuk, baik ia sengaja atau tidak setelah tersadar dari pingsannya.

3. Baligh, yaitu orang yang telah berusia 15 tahun (tahun Qamariah), atau telah ada tanda-tanda baligh yang lain, seperti keluar mani dengan sebab bermimpi jimak bagi laki-laki, atau keluar haid bagi perempuan yang berumur sekurang-kurangnya sembilan tahun (tahun Qamariah). Ibnu Hazmin berpendapat anak-anak yang telah mumayyiz itu diperintahkan untuk melakukan puasa Ramadhan bila ia sanggup berpuasa dan puasanya sah (As-Syarbaini, n.d: 436).

4. Suci dari haid dan nifas, untuk berpuasa perempuan disyaratkan bersih dari haid, nifas dan wiladah (bersalin), baik pada saat darah keluar banyak, atau sedikit, baik anak lahir itu sempurna ataupun yang dilahirkan itu segumpal darah atau daging, maka ia tidak sah berpuasa hingga bersih darinya. Karena itu, jika orang yang haid atau nifas dan wiladah berpuasa, berarti ia telah melakukan perbuatan haram. Puasa tidak sah dan harus mengqadhanya (As-Syarbaini, n.d: 433).

5. Dalam waktu yang dibolehkan puasa, maka puasa tidak sah apabila dilakukan di luar waktu yang telah dibolehkan oleh syara'. Karena tidak dibenarkan oleh syar'i, seperti hari raya idul fitri, idul adha dan puasa pada hari tasyriq. (Zuhaily, 1989: 611)

6. Mampu berpuasa. Orang yang lemah karena terlalu tua, sakit atau musafir yang dapat membawa mudharat pada 
dirinya dengan sebab berpuasa, maka tidak wajib puasa baginya. Firman Allah dalam Alquran:

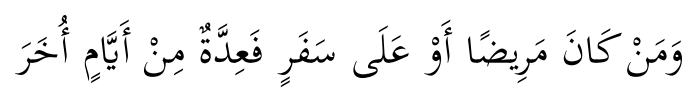

"Dan barang siapa sakit atau dalam perjalanan (lalu ia berbuka) maka (wajib baginya berpuasa) sebanyak hari yang ditinggalkannya pada hari-hari yang lain". (Q.S. Al-Baqarah [2]: 185)

Selanjutnya firman Allah Swt:

$$
\text { وَعَلَى الَّذِينَ يُطِيقُونَهُ فِذْيَة طَعَامُ مِسنكِينٍ }
$$

"Dan atas orang-orang yang merasa berat untuk berpuasa maka ia wajib membayar fidyah, yaitu memberi makan orang miskin". (Q.S. Al-Baqarah [2]: 184)

Dari kedua ayat di atas dapat dipahami bahwa orang sakit boleh meninggalkan puasa Ramadhan bila dengan ia berpuasa akan mengakibatkan bertambah sakit yang dideritanya. Tapi ia wajib mengqadha puasa pada hari-hari yang lain di luar bulan Ramadhan sebanyak puasa yang ditinggalkannya apabila telah sembuh dari sakitnya.

Dalam ayat di atas juga memberikan keterangan bahwa menjadi seorang musafir juga mendapatkan keringanan untuk boleh tidak berpuasa di bulan Ramadhan. Ulama Syafiliyah mensyaratkan bahwa perjalanan itu harus mempunyai jarak tempuhnya sejauh dua marhalah dan memenuhi ketentuan yang disyari'atkan untuk mengqashar shalat, tidak bermaksud untuk melakukan perbuatan maksiat. Maka perjalanan yang seperti ini agama membolehkan seorang musafir untuk berbuka. Akan tetapi, bila perjalanan itu tidak membuat merasa kesulitan berpuasa agama menganjurkan sebaiknya ia tetap berpuasa walaupun perjalanan yang ditempuh oleh orang tersebut telah memenuhi kriteria-kriteria yang telah ditentukan oleh syari'at.

Demikian pula halnya orang yang merasa berat untuk melakukan puasa ramadhan seperti orang terlalu tua atau sakit yang tidak diharap sembuh lagi, dan wanita hamil atau menyusui khawatir bahwa puasa akan membahayakan dirinya, atau membahayakan anaknya maka mereka boleh berbuka. Dalam hal ini penulis akan membahas lebih dalam pada bab selanjutnya.

Dalam kata يطيقيق juga termasuk orang yang bekerja keras untuk penghidupannya yang apabila dengan berpuasa itu akan membinasakan dirinya dan keluarganya, maka Allah memberikan keringanan dengan syarat membayar fidyah, dan tidak wajib mengqhada puasa apabila ia bekerja setiap harinya (Muhammad, 1996: 67).

Adapun tujuan dari rukhsah (keringanan) yang diberikan Allah SWT pada hambaNya bukanlah sekedar terlepas dari menjalankan perintah Allah tapi sebagai tanda bahwa Allah itu sayang pada hambaNya karena memang ada beberapa kondisi serta situasi sulit yang dialami oleh manusia yang menyebabkan manusia itu tidak bisa dan tidak mampu untuk menjalankan perintah yang telah ditetapkan oleh Allah SWT pada saat itu.

Semua syarat-syarat wajib puasa ramadhan di atas merupakan syaratsyarat puasa yang telah disepakati oleh ulama Hanafiyah dan Syafi'iyah. Apabila semua yang tersebut di atas telah terpenuhi oleh orang yang akan berpuasa maka mereka sepakat mengatakan puasa 
wajib dilaksanakan bagi setiap muslim yang beriman.

Adapun syarat wajib puasa ramadhan yang perselisihkan oleh ulama Hanafiyah dan Syafi'iyah hanya satu yaitu masalah niat dalam berpuasa. Ulama Hanafiyah berpendapat bahwa niat merupakan syarat sah puasa. Sedangkan ulama Syafi'iyah berpendapat niat merupakan rukun puasa Ramadhan. Walaupun demikian, niat tidak boleh ditinggalkan dalam melakukan ibadah puasa karena puasa tidak sahnya.

\section{Rukun Puasa}

Adapun rukun-rukun puasa Ramadhan menurut pendapat ulama para fuqaha' adalah sebagai berikut:

1. Niat, ulama fuqaha' berbeda pendapat dalam memposisikan niat sebagai rukun dari puasa. Sebagian ulama berpendapat bahwa niat itu merupakan rukun dari puasa dan apabila seseorang tidak berniat dalam melakukan puasa Ramadhan atau keluar dari niat puasa maka puasanya tidak sah (Al-Husaini, n.d: 205). Pendapat ini dikemukakan oleh ulama dari mazhab Syafi'iyah. Sedangkan sebagian ulama yang lain mengemukakan bahwa niat merupakan salah satu dari syarat-syarat puasa. Pendapat ini dikemukakan oleh ulama Hanafiyah.

2. Menahan diri dari segala yang membatalkan puasa. Seperti makan, minum, jimak, dan sebagainya. Untuk lebih jelasnya penulis akan menjelaskannya pada bagian tentang hal-hal yang membatalkan puasa pada skripsi ini.

3. Berpuasa mulai dari terbit fajar sampai terbenam matahari. Yang dimaksud dengan mulai dari fajar di sini adalah fajar siddiq.

\section{Hal-hal yang Membatalkan Puasa}

Puasa menjadi batal disebabkan beberapa hal di bawah ini:

1. Makan dan minum

2. Memasukkan sesuatu ke tenggorokan tanpa melalui mulut.

3. Melakukan hubungan seksual (bersetubuh) di siang hari.

4. Keluar darah haid, nifas dan wiladah

5. Keluar mani (sperma) dengan sebab mubasyarah (bersentuhan kulit tanpa alas) atau dengan onani.

6. Gila

7. Berniat berbuka

8. Murtad

\section{Pandangan Hanafiyah tentang Wanita Hamil dan Menyusui Meninggalkan Puasa Ramadhan}

Sebagaimana yang telah penulis jelaskan dalam bahasan masalah skripsi ini bahwa yang penulis maksud dengan meninggalkan puasa Ramadhan adalah dalam hal wanita hamil dan menyusui yang tidak mampu (merasa berat) dalam melakukan puasa lantaran khawatir atas keselamatan dirinya dan anaknya. Oleh karena itu, pembahasan lebih lanjut akan menjelaskan bagaimana pandangan ulama Hanafiyah terhadap akibat hukum wanita hamil dan menyusui bila ia meninggalkan puasa Ramadhan lantaran khawatir atas keadaan dirinya dan anaknya.

Ulama Hanafiyah berpendapat bahwa apabila seorang wanita dalam keadaan hamil dan menyusui di bulan Ramadhan lalu ia meninggalkan puasa lantaran takut atas dirinya dan anaknya, 
atau takut atas dirinya saja tidak atas anaknya, atau takut atas anaknya tidak atas dirinya maka wajib qadha dan tidak wajib membayar fidyah atau kafarat. Karena sesungguhnya ia tidak berdosa dengan meninggalkan puasa. (AlSarkhasi, n.d: 99)

Dalam penetapan wajib qadha dan tidak wajib membayar fidyah atau kafarat sebagai akibat hukum dari meninggalkan puasa Ramadhan lantaran hamil dan menyusui, ulama Hanafiyah mendasari pendapatnya dengan beberapa alasan sebagai berikut :

1. Berdasarkan kepada firman Allah Swt:

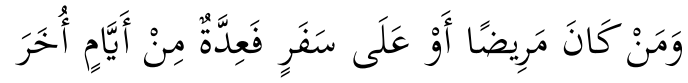

"Dan barang siapa sakit atau dalam perjalanan (lalu ia berbuka) maka (wajib baginya berpuasa) sebanyak hari yang ditinggalkannya pada hari-hari yang lain". (Q.S. Al-Baqarah [2]: 185)

Dari ayat tersebut ulama Hanafiyah bahwa orang sakit atau orang yang dalam menempuh perjalanan (musafir) boleh meninggalkan puasa bila memang tidak mampu untuk melakukan puasa atau memang ada larangan dari medis demi keselamatan jiwanya tapi mereka wajib mengqadha puasanya tersebut bila telah sembuh dari sakit yang dideritanya atau telah selesai melakukan perjalanan bagi si musafir.

Begitu juga dengan wanita hamil bila ia meninggalkan puasa Ramadhan karena khawatir atas dirinya atau anaknya, secara mutlak ulama Hanafiyah menyatakan wanita hamil dan menyusui hanya diwajibkan mengqadha puasa saja. Alasannya adalah karena wanita hamil tersebut sama kedudukannya dengan simusafir. Musafir bila meninggalkan puasa Ramadhan maka ia tidak dikenakan kewajiban kecuali qadha saja.

2. Berdasarkan hadist Rasulullah SAW:

$$
\begin{aligned}
& \text { اخبرنا عمـروبن منصسورقال حـدثنا مسلم بـن ابراهيم } \\
& \text { عن وهيب بن خالد قال حدثنا عبد الله بن سوادة } \\
& \text { القشيرى عن أبيه عن أنس بن مالك : رجل منهم }
\end{aligned}
$$

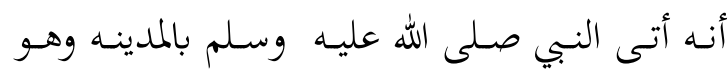

$$
\begin{aligned}
& \text { يتغـدى فقـال له النبي صلى الله عليه وسـلم ان الله } \\
& \text { عزوجل وضع للمسافر الصيام وشطر الصالاة وعن } \\
& \text { الحبلى المرضع.(رواه النسائي) }
\end{aligned}
$$

"Menceritakan Umar bin Mansyur ia berkata menceritakan muslim bin Ibrahim dari Wuhaibi bin Khalid ia berkata menceritakan 'Abdullah bin Sawadah al-Qusyairi dari bapaknya dari Anas bin Malik: seorang laki-laki dari mereka datang kepada Nabi SAW di Madinah dan Nabi dalam keadaan makan, lalu Nabi SAW berkata kepada laki-laki itu: Mari kita makan!, Laki-laki itu menjawab: "Saya puasa ", Lalu Nabi SAW bersabda kepada laki-laki itu: "Sesungguhnya Allah telah meringankan puasa bagi musafir dan meringankan shalat. Dan juga Allah memberi keringanan kepada perempuan yang sedang menyusui dan hamil". (HR. An-Nasa'i) (Al-Suyuthi, 1930: 190).

Berdasarkan hadis di atas ulama Hanafiyah berpandangan bahwa posisi serta kedudukan hukum rukhshah pada musafir sama dengan hukum rukhshah bagi wanita hamil dan 
menyusui, karena 'athaf (عطف) antara dua kalimat di atas tanpa ada istiknaf (استئناف) (Al-Razhi, n.d: 181).

3. Ijma' Ulama Hanafiyah

Berdasarkan penafsiran terhadap maksud dari firman Allah Swt:

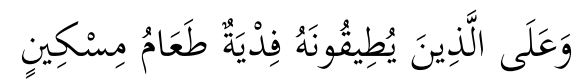

"Dan wajib bagi orang-orang yang berat menjalankannya membayar fidyah, yaitu memberi makan seorang miskin". (Q.S. Al-Baqarah [2]: 184)

Ulama Hanafiyah berpendapat bahwa ayat tersebut bukan ditujukan sebagai dasar hukum bagi wanita hamil dan menyusui akan tetapi ditujukan kepada orang tua laki-laki dan perempuan yang lanjut usia (manula). Oleh sebab itu ulama Hanfiyah tidak mengambil ayat tersebut menjadi dalil dari rukhsah bagi wanita hamil dan menyusui akan tetapi ayat tersebut adalah untuk orang tua lanjut usia.

Sebagaimana yang telah diterangkan dalam kitab Al-Banayah Fii Syarhi al-Hidayah, karangan Abi Muhammad Mahmud ibn Ahmad al'Aini mengatakan bahwa ayat di atas diturunkan oleh Allah adalah untuk orang tua yang lanjut usia, sebagaimana ia berkata :

والاصل في هذا الحلكم الفديـة : قوله تعالى : وَعَلَّى

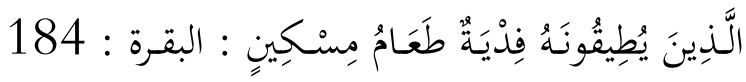

$$
\text { نزلت في الشيخ الفاني. }
$$

"Dasar hukum fidyah yaitu firman Allah SWT: "Dan wajib bagi orang-orang yang berat menjalankannya membayar fidyah, yaitu memberi makan seorang miskin" ayat ini diturunkan (ditujukan) kepada orang tua lanjut usia". (Q.S. Al-Baqarah [2]: 184) dicantumkan pada (Al-'Aini, n.d: 295).

Pernyataan tersebut berdasarkan hadis dari ibnu Abbas sebagai berikut:

$$
\begin{aligned}
& \text { حـدثنا أبو أحمـد بـن عبـد الله وكيل أبي صخرة, ثنـا }
\end{aligned}
$$

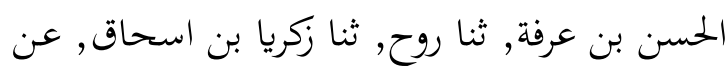

$$
\begin{aligned}
& \text { عمر بن دنار , عن عطاء أنه سمع ابن عباس يقرؤها }
\end{aligned}
$$

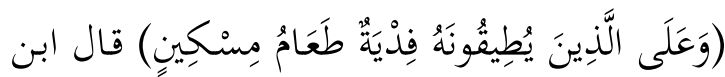

$$
\begin{aligned}
& \text { عباس: "ليست بمنسوخة, هو الشيخ الكبير والمرأة }
\end{aligned}
$$

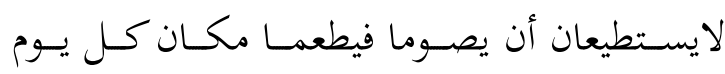

$$
\begin{aligned}
& \text { مسكينا " (رواه الدارالقطني) وهذا صحيح. }
\end{aligned}
$$

"Menceritakan Ahmad bin Abdullah Wakil Abi Shakhrah, bersama al-Hasan bin 'Urfah, Ruuh, Zakaria bin Ishaq, dari Umar bin Dinar, dari 'Atha' bahwa sesungguhnya dia mendengar Ibnu Abbas membaca ayat ("Dan wajib bagi orang-orang yang berat menjalankannya, membayar fidyah, yaitu memberi makan seorang miskin") Ibnu Abbas berkata: Ayat tersebut tidak dimansukh, yaitu orang tua laki-laki dan perempuan yang tidak sanggup untuk berpuasa maka ia wajib memberi makan orang miskin setiap hari". (HR: AdDaaruquthni) hadis ini tergolong shahih (Ad-Daaruqutni, n.d: 195).

4. Bahwa syarat dari wajib fidyah adalah bila seseorang ( العجز المستدام), yaitu lemah yang terus menerus dari mengqadha yang tidak ada harapan untuk kuasa dari mengqadha sampai akhir hayatnya, maka ini hanya ada pada orang tua lanjut usia. Oleh karena itu, tidak ada wajib fidyah bagi musyafir, orang sakit, wanita hamil dan 
menyusui dan setiap orang yang membatalkan puasa karena uzur karena masih ada harapan kemampuan untuk mengqadha puasa.

5. Bahwa sesungguhnya fidyah merupakan ganti dari mengqadha. Sedangkan kuasa atas mengqadha pada dasarnya terlarang menjadikan fidyah sebagai gantinya. Oleh karena itu, kami berpendapat sekiranya orang tua yang lanjut usia apabila ia ada prioritas untuk membayar fidyah kemudian ia tetap puasa maka batallah kewajiban fidiyah padanya (Al-Kasani, n.d: 105).

6. Bahwa menempatkan hukum qiyas pada wanita hamil dan menyusui dengan (الشيخ الفاني ), yaitu orang tua lanjut usia , itu telah menyalahi ketetapan hukum qiyas, artinya tidak ada jalan qiyas di sini. Dan berbuka dengan sebab anak atau janin tidaklah dalam makna ( الشيخ الفاني ), karena orang lanjut usia lemah dari wajib puasa atasnya. Untuk jalan tetap berlakunya hukum Allah pada orang lanjut usia maka ditetapkanlah fidyah sebagai ganti dari puasa yang ditinggalkannya.

7. Dan pada ashal anak tidak wajib puasa. Maka bagaimana menjadikan anak itu sebagai ganti dengan tanpa ashal. Maka adalah qiyas itu dha'if, karena ada perbedaan (Al-'Aini, n.d: 295).

8. Bahwa sesungguhnya orang hamil dan menyusui diposisikan pada hukum orang sakit (Ash-Shabuni, n.d: 209). Maka tidak wajib atas wanita hamil dan menyusui membayar fidyah sebagaimana juga pada orang sakit.

9. Orang tua lanjut usia tidak mungkin lagi wajib qadha puasa padanya karena ia kondisi dan umurnya. Maka tidak akan mungkin ada harapan padanya untuk mengqadha puasa walaupun hanya satu hari. Oleh karena itu inilah dasar dia hanya wajib fidyah saja. Akan tetapi wanita hamil dan menyusui termasuk orang-orang yang 'uzur tidak terus menerus, maka atasnya hanya wajib qadha saja. Oleh karena apabila wajib atas mereka qadha sekaligus fidyah sungguh bergabunglah dua ganti, yaitu pertama qadha dan kedua fidyah dan itu tidak boleh. Dan tidak mungkin menghimpun keduanya bahwa sesungguhnya yang wajib puasa salah satu dari keduanya, yaitu seorang ibu saja, sedangkan anak tidak wajib puasa.

Demikianlah beberapa argumentasi yang telah dikemukakan oleh ulama Hanafiyah sebagai akibat hukum bagi wanita hamil dan menyusui yang meninggalkan puasa Ramadhan lantaran khawatir atas keselamatan dirinya dan anaknya, sekaligus menetapkan wajib qadha dan tidak wajib membayar fidyah terhadap keduanya secara mutlak.

\section{Pandangan Syafi'iyah tentang Wanita Hamil dan Menyusui Meninggalkan Puasa Ramadhan}

Ulama Syafi'iyah berpendapat bahwa wanita yang sedang mengalami masa kehamilan atau sedang menyusui, jika ia takut akan dirinya dan anaknya atau takut atas keselamatan anaknya saja, lalu ia tinggalkan puasa Ramadhan maka ia tidak berdosa, tetapi ia wajib qadha dan membayar fidyah (memberi makan orang miskin) satu hari satu mud (Ibrahim, n.d: 178). Namun jika ia takut atas dirinya saja 
maka ia wajib qadha dengan tidak membayar fidyah (Al-Bajury, n.d: 300). Pendapat yang kedua ini sama dengan pendapat yang dikemukakan oleh ulama Hanafiyah.

Berdasarkan pernyataan seperti keterangan di atas jelas bahwa ulama Syafi'iyah membagi kepada dua kewajiban yang harus dilaksanakan oleh seorang wanita hamil dan menyusui bila ia meninggalkan puasa Ramadhan, pertama bila ia meninggalkan puasa lantaran takut pada dirinya maka ia wajib qadha saja. Kedua bila meninggalkan puasa karena takut atas keselamatan anaknya dan dirinya maka ia wajib mengqadha sekaligus wajib membayar fidyah. Dari dua pendapat ulama Syafi'iyah nyata bahwa golongan Syafi'iyah menolak penetapan wajib qadha saja secara umum terhadap akibat hukum bagi wanita hamil dan menyusui bila ia meninggalkan puasa Ramadhan.

Penolakan ulama Syafi'iyah terhadap penetapan secara umum wajib qadha saja itu didasari oleh beberapa alasan atau pertimbangan, sebagai berikut:

1. Firman Allah Swt:

$$
\text { وَعَلَى الَِّْينَ يُطِيقُونَهُ فِدْيَةُ طَعَامُ مِسنكِينِ }
$$

"Dan atas orang-orang yang merasa berat untuk mengerjakan puasa, wajib ia membayar fidyah, yaitu memberi makan orang miskin". (Q.S. Al-Baqarah [2]: 184)

Menurut ulama Syafi'iyah bahwa melihat keumuman redaksi ayat maka wanita hamil dan menyusui masuk dalam maksud النَذِينَ يُطِيقُونَهُ sama statusnya dengan orang tua yang lanjut usia. Yaitu dari segi kondisinya yang merasa berat atau lemah dalam melaksanakan puasa Ramadhan ketika dia hamil dan menyusui. Oleh karenanya ia wajib mengqadha serta membayar fidyah (AlMuqaddasy, n.d: 100).

2. Berdasarkan hadis Rasulullah yang diterima dari sahabat Rasulullah SAW yaitu:

a. Ibn Abbas

Menurut Ibnu Abbas bahwa bunyi surat al-Baqarah ayat 184 tentang "orang-orang yang merasa berat melakukan puasa Ramadhan "Telah di dimansukh oleh ayat yang sesudahnya yaitu: وان تصـوم خـير لكـــ terkecuali wanita hamil dan menyusui, sebagaimana bunyi hadist di bawah ini:

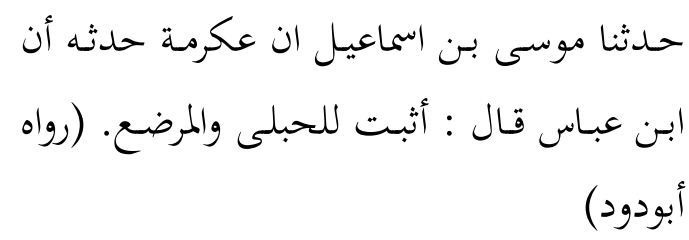

"Menceritakan Musa ibn Ismail bahwa Ikrimah telah menceritakannya bahwa Ibnu Abbas berkata: "Tetap (ayat itu) bagi orang hamil dan menyusui". (HR: Abu Daud) (AsSyaukani, n.d: 297).

b. Hadis Anas bin Malik:

$$
\begin{aligned}
& \text { حدثنا أبوكريب ويوسف بن عيسى قالا : حدثنا } \\
& \text { وكيع, حدثنا أبو هلال, عن عبد الله بن سوادة } \\
& \text { عن أنس بـن مالك رجل مـن بني عبـد الله بـن } \\
& \text { كعـب قـال : أغـارت علينـا خيـل رسـول الله } \\
& \text { صلى الله عليه وسلم فأتيت رسول الله صلى الله } \\
& \text { عليه وسلم فوجدته يتغدى, فقال : "ادن فكل" } \\
& \text { فقلـت اين صـائم, فقـال : "ادن أحسـثك عـن }
\end{aligned}
$$




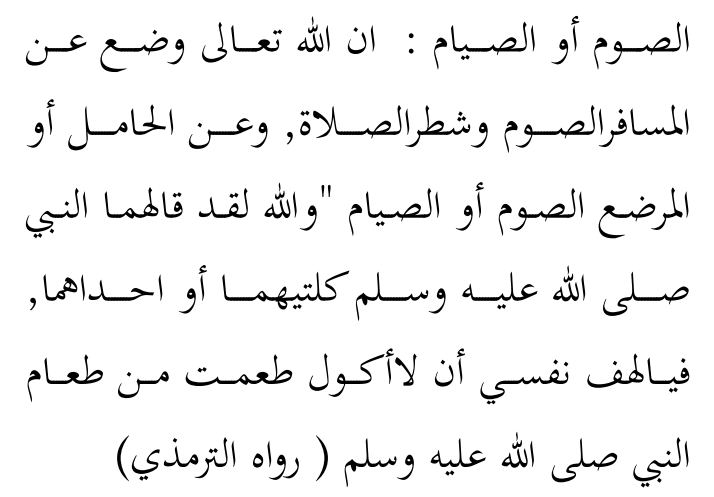

"Menceritakan Abu Kuraib dan Yusuf bin 'Isa keduanya berkata: menceritakan Waki', menceritakan Abu Hilal dari Abdullah bin Suwadah dari Anas bin Malik. Seorang laki-laki dari Bani Abdullah bin Ka'bin berkata: Berhenti atas kami sekawanan kuda Rasulullah SAW, lalu aku menemui Rasulullah, maka aku dapati beliau Rasul sedang makan, Rasul berkata: "Kemarilah kita maka", Lalu aku menjawab: Aku puasa, lalu beliau Nabi bersabda: "Kemarilah, aku sampaikan padamu tentang puasa: "Sesungguhnya Allah telah meringankan orang musafir hanya setengah shalat, dan meringankan puasa bagi perempuan hamil dan perempuan menyusui. Demi Allah, Rasulullah SAW telah menceritakan tentang keduanya atau salah satunya. "Alangkah mengeluh diriku, sebagaimana aku tidak mau makan dari makanan Rasulullah $S A W^{\prime \prime}$. (HR: Turmudzi) (Saurah, n.d: 180-181).

c. Sunan Abu Daud diterangkan:

$$
\text { حدثنا ابن المثنى, ثنا ابن أبى عدى , عن سعيد }
$$

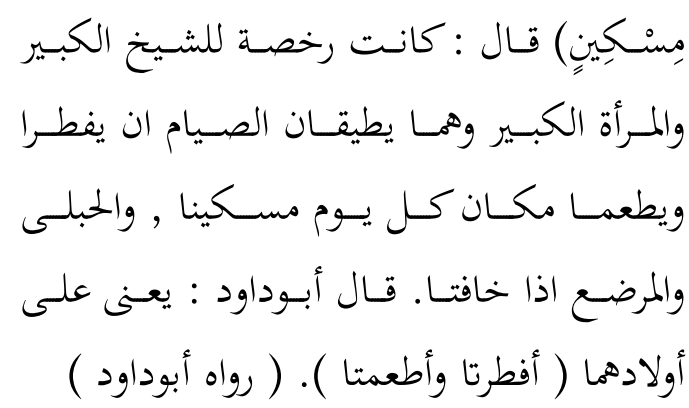

"Menceritakan ibn mastna berdua ibn Abi 'Addiyi, dari Sa'id dari Qatadah dari 'Urwah dari Sa'id ibn Jabir dari Ibn Abbas :( "Dan atas orang-orang yang merasa berat untuk mengerjakan puasa, wajib ia membayar fidyah, yaitu memberi makan orang miskin."), dia berkata:"Adalah ayat tersebut merupakan rukhsah bagi wanita dan laki-laki lanjut usia. Dan keduanya berat untuk puasa maka ia wajib memberi makan tiap-tiap hari satu orang miskin. Dan orang hamil dan menyusui apabila ia takut, kata Abu Daud yaitu atas anak-anaknya., maka mereka berbuka maka mereka juga memberi makan (orang miskin)". (HR: Abu Daud) (Al-Sajsatani, 1952: 541)

d. Tartib Musnat Imam Syafi'i:

$$
\begin{aligned}
& \text { (أخـبرنا ) مالـك بـن أنسس عـن نافـع بـن عبـــ } \\
& \text { الحسارث, أخسبرنا : أبـن عمـر ســـل عـن المـرأة } \\
& \text { الحامـل اذا خافـت علـى ولـدها قـال : تفطـر } \\
& \text { وتطعم مكان كل يوم مسكينا مدا من حنطة. }
\end{aligned}
$$

"Mengkhabarkan kepada kami oleh Malik bin Anas dari Nafi' bin Abdu al-Haris, mengkhabarkan pada kami: Ibn Umar ditanya orang tentang wanita hamil bila (ia meninggalkan 
puasa ramadhan) karena takut atas keselamatan anaknya, beliau menjawab: Ia boleh berbuka dan memberi makan orang miskin tiap hari satu mud dari gandum". (AlKaustari, 1990: 278)

Dari keterangan hadist-hadist di atas dapat diambil kesimpulan bahwa hadist pertama dan kedua menafsirkan akan maksud ayat 184 surat al-Baqarah di mana wanita yang hamil dan menyusui bila meninggalkan puasa Ramadhan itu tergolong sebagai salah satu golongan yang mendapat rukhsah (keringanan) untuk tidak berpuasa, artinya boleh berbuka atau boleh meninggalkan puasa Ramadhan ketika ia tidak mampu untuk menunaikannya. Maksudnya dispensasi yang diberikan Allah SWT bukan semata-mata tertuju kepada orang tua lanjut usia saja tetapi juga pada wanita hamil dan menyusui.

Kemudian pada hadist yang ketiga lebih mempertegas tentang kewajiban yang harus dibayar oleh wanita hamil dan menyusui ketika ia telah meninggalkan puasa Ramadhan lantaran ada kekhawatiran terhadap keselamatan anak serta jiwa seorang ibu, kekhawatiran itu seperti lemahnya pertumbuhan janin, menyebabkan keguguran terhadap kandungan, atau anak lemah baik dari fisik maupun mental. Dengan bermacam bentuk kekhawatiran di atas maka Allah memberikan rukhsah pada seorang wanita hamil dan menyusui untuk tidak berpuasa, di mana seorang ibu boleh meninggalkan puasa Ramadhan. Dengan ketentuan wanita itu wajib membayar fidyah dengan memberi makan kepada orang-orang miskin.
Pada hadis yang keempat menjelaskan bahwa seseorang bertanya kepada Ibnu Umar tentang wanita hamil bila ia takut akan keselamatan janin yang dikandungnya maka apa yang harus ia lakukan? beliau menjawab: "Boleh berbuka dan wajib memberikan makan orang miskin (membayar fidyah).

Dari keterangan Ibnu Umar r.a jelas bahwa perempuan hamil wajib membayar fidyah bila ia meninggalkan puasa Ramadhan lantaran khawatir terhadap anaknya.

3. Ijma' Ulama Syafi'iyah

Ijma' Ulama Syafi'iyah juga menggunakan metode Dalil 'Akliyah, yaitu sebagai berikut:

a. Ulama Syafi'iyah berpendapat bahwa memposisikan wanita hamil dan menyusui bisa dikiyaskan dengan orang tua lanjut usia yang tidak kuat berpuasa dengan illat " sama-sama lemah" dalam mengerjakan puasa Ramadhan. Sehingganya wanita hamil dan menyusui wajib membayar fidyah bila ia takut atas keselamatan anaknya dan janin yang dikandungnya.

b. Bahwa wanita hamil dan menyusui itu berpuasa lantaran mengambil manfaat dari dua jiwa seseorang (anak/janin) pada hal pada dasarnya dirinya tidak ada merasa takut untuk tidak berpuasa. Sebagaimana kutipan di bawah ini:

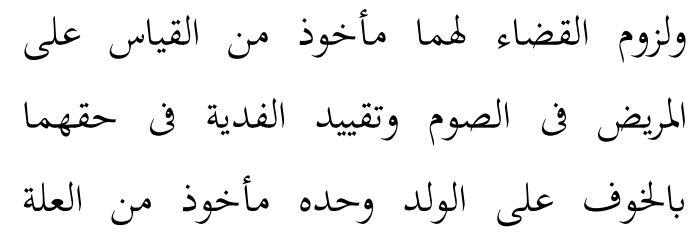




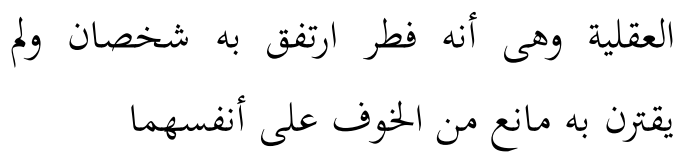

"Dan wajib qadha bagi keduanya (wanita hamil dan menyusui) itu diambilkan dari mengkiyaskan kepada orang sakit dalam hal puasa dan mengkaitkan wajib fidyah pada hak keduanya yang disebabkan takut atas anaknya saja itu diambilkan dari illat 'akliyah, adalah karena sesungguhnya ia berbuka lantaran ada manfaat terhadap dua jiwa seseorang (ibu dan janin atau anak) pada hal pada dasarnya dirinya tidak ada merasa takut untuk tidak berpuasa". (AlAzdhari, n.d: 411-412)

Syekh Muhammad Khatib alSyarbaini menjelaskan dalam kitabnya yang berjudul "Mughni al-Muhtaaj" bahwa wajib qadha beserta fidyah bagi wanita hamil dan menyusui itu yang takut atas keselamatan anaknya adalah untuk menyelamatkan anak adam yang ma'syum lagi mulia dari kebinasaan. Sebagaimana kutipan di bawah ini:

$$
\text { ولى هلأصح أنه يلحق بالمرضع من أفطر لانقاذ مشرف }
$$

"Menurut pendapat ash-shah, bahwa wajib qadha dan fidyah bagi wanita menyusui itu karena menyelamatkan anak adam yang ma'syum lagi mulia dari kebinasaan". (As-Syarbaini, n.d: 441)

Demikianlah alasan-alasan serta argumentasi yang telah dikemukakan oleh ulama Syafi'iyah dalam menentukan qadha dan fidyah sebagai akibat hukum terhadap wanita hamil dan menyusui yang meninggalkan puasa ramadhan karena takut atas dirinya dan anaknya, sekaligus sebagai penolakan terhadap membayar qadha saja terhadap keduanya.

Berdasarkan pembahasan di atas dapat dikemukakan analisis penulis bahwa dengan memperhatikan beberapa pandangan ulama Hanafiyah dan Ulama Syafi'iyah tentang akibat hukum terhadap wanita hamil dan menyusui yang meninggalkan puasa Ramadhan lantaran takut akan keselamatan dirinya dan anaknya jelaslah bahwa perbedaan pendapat itu hanya dalam menetapkan wajib fidyah sebagai akibat hukumnya sedangkan mengenai qadha disepakati oleh keduanya.

Adapun latar belakang atau dasar terjadinya perbedaan pendapat terhadap penetapan wajib fidyah terhadap wanita hamil dan menyusui yang meninggalkan puasa ramadhan disebabkan oleh beberapa hal, di antaranya:

1. Perbedaan pendapat dalam memahami maksud dari firman Allah SWT yang terdapat dalam surat al-Baqarah ayat 184. Di mana ulama Hanafiyah berpendapat bahwa maksud ayat itu adalah ditujukan kepada orang tua lanjut usia. Sedangkan ulama Syafi'iyah berpendapat bahwa di samping orang tua renta juga terhadap wanita hamil dan menyusui.

2. Perbedaan dalam mengambil hadist Nabi SAW sebagai dalil yang kedua setelah al-Qur'an. Di mana ulama Hanafiyah berpendapat dengan hadist yang disampaikan oleh Anas r.a yang menyatakan bahwa kedudukan rukhsah pada wanita hamil dan menyusui sama dengan musafir. Sedangkan ulama Syafi'iyah 
mengambil hadist yang diriwayatkan oleh Ibnu Umar r.a dan Ibnu Abbas yang menyatakan bahwa wanita hamil dan menyusui yang meninggalkan puasa ramadhan wajib membayar fidyah setelah mengqadha puasa bila ia khawatir atas keselamatan anaknya.

3. Melihat kualitas hadist yang diambil oleh ulama Hanfiyah, ternyata hadist yang telah diriwayatkan oleh Anas bin Malik al-Ka'bain r.a adalah Hasan sebagai mana yang telah dikemukakan oleh Syekh al-Bani dan Abu 'Isa dan atTurmuzi, karena tidak ada hadist lain yang diriwayatkannya selain satu hadist itu saja. Sedangkan hadist yang telah diriwayatkan oleh Ibn Umar adalah hadistnya adalah Shahih. Sebagaimana yang telah dikemukakan oleh Syekh al-Bani. Di samping itu juga didukung oleh pendapat sahabat dalam menafsirkan surat al-Baqarah ayat 184 yang mengatakan bahwa hukum wajib fidyah bukan saja dibebankan pada orang yang lanjut usia juga terhadap wanita hamil dan menyusui bila keduanya meninggalkan puasa dikarenakan takut atas keselamatan janin atau anak yang menyusui padanya.

Berdasarkan beberapa keterangan di atas penulis dalam hal menentukan kecenderungan terhadap perbedaan pendapat antara ulama Hanafiyah dan ulama Syafi'iyah tentang kewajiban yang harus dibayarkan oleh seorang wanita hamil dan menyusui ketika ia meninggalkan puasa lantaran takut atas keselamatan janin dan anaknya penulis beranggapan bahwa pendapat ulama Syafi'iyah lebih sahih dan lebih kuat, karena ia berdasarkan nash yang nyata sedangkan hadist dari Anas bin Malik hanya menerangkan adanya rukhsah bagi musafir dan wanita hamil tanpa menyentuh tentang fidyah.

Kemudian tentang kualitas hadist yang dipakai oleh kedua golongan Hanafiyah dan Syafi'iyah. Hadist yang dipakai oleh ulama Syafiliyah berstatus sahih dan hadist yang dipakai oleh ulama Hanafiyah berstatus hasan. Walaupun keduanya sama-sama boleh diamalkan tetapi hadist yang berkualitas sahih lebih mendahulukan dari hadist yang berkualitas hasan.

\section{PENUTUP}

\section{Kesimpulan}

Adapun yang menjadi penyebab perbedaan pendapat antara ulama Hanafiyah dan ulama Syafi'iyah disebabkan oleh:

1. Berbedanya mereka dalam penggunaan dalil, Hanafiyah berdasarkan kepada hadist yang diriwayatkan oleh Anas bin Malik al-Ka'bain sedangkan Syafi'iyah berdasarkan kepada hadist dari Ibnu Umar dan Ibnu Abbas.

2. Berbeda mereka dalam memahami firman Allah SWT surat al-Baqarah ayat 184. Ulama Hanafiyah berpendapat ayat tersebut ditujukan kepada laki-laki dan wanita yang telah lanjut usia (tua renta) saja. Ulama Syafi'iyah mengatakan bukan semata-mata untuk laki-laki dan wanita tua renta saja, juga terhadap wanita hamil dan menyusui berdasarkan hadist dari Ibnu umar.

3. Berbedanya mereka dalam mengkatagorikan kata-kata ( يطيقونه )dalam surat al-Baqarah ayat 184. Ulama Hanafiyah berpendapat bahwa wanita hamil dan menyusui 
sama kedudukan hukumnya dengan orang sakit dan musafir yang tidak wajib membayar fidyah tapi puasa saja. Sedangkan ulama Syafiliyah berpandangan bahwa kedudukan wanita hamil dan menyusui sama hukumnya dengan laki-laki dan wanita yang lanjut usia (manula) karena berdasarkan hadist dari ibn umar.

4. Perbedaan mereka dalam menentukan kewajiban yang harus dibayar oleh wanita hamil dan menyusui ketika mereka meninggalkan puasa ramadhan. Ulama Hanafiyah berpendapat bahwa secara mutlak tanpa memandang alasan wanita hamil dan menyusui yang meninggalkan puasa Ramadhan hanya dikenakan wajib qadha. Sedangkan ulama Syafi'iyah dalam hal ini mengemukakan dua pendapat, pertama bila wanita hamil dan menyusui meninggalkan puasa karena takut atas keselamatan dirinya saja maka ia wajib qadha puasa. Kedua bila ia meninggalkan puasa ramadhan takut akan keselamatan dirinya serta anaknya atau anaknya saja maka ia wajib mengqadha puasa sekaligus membayar fidyah.

Dari keempat kriteria perbedaan pendapat ulama di atas menurut hemat penulis pendapat ulama Syafi'iyah lebih kuat dan lebih pantas untuk diamalkan yang mengatakan bahwa wanita hamil dan menyusui yang meninggalkan puasa ramadhan karena takut atas keselamatan janin yang dikandungnya dan anaknya sekaligus kesehatan badannya maka ia wajib qadha puasa juga membayar fidyah, dengan pertimbangan sebagai berikut:

1. Karena kekhawatiran wanita tersebut bukan lantaran takut pada dirinya tapi khawatir atas janin dan anak. Artinya di mana pada dasarnya ia mampu untuk melaksanakan berpuasa ramadhan tetapi karena menimbang janin atau anak yang masih menyusui terpaksa tinggalkan puasa.

2. Karena Ulama Syafi'iyah mempunyai hadist pendukung lainnya yang setelah di telusuri dari pendapat ulama hadist yang dipakai oleh Syafi'iyah adalah hadistnya shahih sedangkan Ulama Hanafiyah hasan, dan juga lebih rasionalnya alasan yang digunakan oleh Syafi'iyah.

3. Dalil yang dipakai oleh ulama Hanafiyah adalah hanya satu hadist saja yaitu hadist hasan. Ulama Syafi'iyah memakai dalil al-qur'an yang didukung oleh hadist shahih.

4. Rukhsah yang diambil oleh Syafi'iyah lebih spesifik yaitu melihat niat dari wanita hamil dan menyusui tersebut sedangkan Hanafiyah memandang secara mutlak tanpa memandang niat sehingga membuka kelonggaran yang luas bagi seorang wanita untuk meninggalkan puasa tanpa melihat latar belakangnya. Jadi hendaknya wanita hamil dan menyusui harus memposisikan niatnya ketika mengamalkan rukhsah yang diberikan oleh Allah SWT pada dirinya agar ia dapat mengamalkannya dengan tepat dan benar serta terjauh dari keraguraguan.

\section{Saran}

Pada akhir tulisan ini penulis akan mengemukakan beberapa saran sebagai berikut:

1. Diharapkan kepada seluruh wanita yang sedang hamil dan menyusui 
supaya betul-betul tepat dalam mengambil keputusan apabila mau meninggalkan puasa Ramadhan karena puasa itu merupakan ibadah yang sangat mulia.

2. Diharapkan kepada wanita hamil dan menyusui bila puasa itu tidak memudaratkan pada janin atau anak yang sedang menyusui hendaknya tetaplah berpuasa, karena mengqadha puasa merupakan sesuatu yang sangat berat, lebih-lebih lagi di luar Ramadhan.

3. Diharapkan kepada mahasiswamahasiswi untuk lebih giat menganalisa secara detail tentang permasalahan-permasalahan khilafiyah, sehingga dapat memberikan masukan yang lebih mendekati ke arah kebenaran, sekaligus mengembangkan ilmu pengetahuan di tengah-tengah masyarakat.

4. Kepada mahasiswa-mahasiswi setiap disiplin ilmu yang didapati dari setiap lembaga pendidikan, hendaknya diamalkan dalam kehidupan seharihari.

\section{DAFTAR KEPUSTAKAAN}

Ad-Daaruqutni, A. bin U. (n.d.). Sunan adDaaruqudhni (Juz I). Beirut: Dar alFikr.

Al-'Aini, A. M. M. B. A. (n.d.). al-Banaayah Fi Syarhi al-Hidayah (Juz 3). Beirut: Darul Fikri.

Al-Azdhari, S. A. bin H. bin I. asy-S. (n.d.). Hasyiyah (Juz I). t.tp: Darl al-Fikr.

Al-Bajury, I. (n.d.). Hasyiyah al-Bajuri (Juz I). Indonesia: Maktabah Dahlan.

Al-Bukhari, I. A. A. (1981). Shahih al-
Bukhari. Beirut: Dar al-Fikr.

Al-Husaini, A.-I. T. A. B. ibn M. (n.d.). Kifayatu al-Akhyar fii Hqlli Gayatu alIkhtishar (Juz I). t.tp: Dar al-Ihyai alKitab.

Al-Jaziri, A. (n.d.). al-Figh "ala Mazahib alArba"ah (Juz II). Beirut: Dar al-Fikr.

Al-Kasani, A. B. ibn M. (n.d.). Bada'I asStanaafi' Fii Tartiibi al-Tasyri'. Libanon: Dar al-Kitab al- ilmiyyah.

Al-Kaustari, M. Z. ibn al-H. (1990). Tartib Musnat Abi Abdullah Muhammad bin Idris asy-Syafi'I (Juz I). Indonesia: Maktabah Dahlan.

Al-Muqaddasy, A. M. 'Abdullah bin A. bin M. Q. (n.d.). Al-Mughni 'Ala Mukhtashar al-Kharaqi. Bairut: Darul Kutubi al-' Amaliah.

Al-Razhi, A. B. A. ibn 'Ali. (n.d.). Ahkamil al-Qur'an al-Jashaash (Juz I). t.tp: Dar al-Fikr.

Al-Sajsatani, A. D. S. ibn A. ibn I. al-A. (1952). Sunnan Abi Daud (Juz I). Cairo: Syirkah al- Baktabah.

Al-Sarkhasi, S. (n.d.). al-Mabsuth. Beirut: Darul al-Fikri.

Al-Suyuthi, J. (1930). Sunan al-Nasa'i (Juz III). Bairut: Dar al-Fikr.

Ash-Shabuni, M. 'Ali. (n.d.). Rawai' alBayan Tafsiru Ayatu al-Ahkam Min alQur'an (Juz I). t.tp: Dar al-Kutub alIslamiyah.

As-Syarbaini, M. K. (n.d.). Mughni alMuhtaaj (Juz I). Beirut: Dar al-Fikr.

As-Syaukani, M. ibnu 'Ali ibnu M. (n.d.). Naila al-Authaar (Juz III). t.tp: Dar alFikr.

Ibrahim, I. A. I. (n.d.). al-Muhazzab. (J. I, 
Ed.). t.tp: Darul al-Fikr.

Muhammad, I. (1996). Puasa Bersama Rasulullah. Bandung: Al-Bayan.

Nizam. (n.d.). al-Fatawa 'Amrikiiyah. Beirut: Dar al-Kutub.

Qardhawi, Y. (1997). Figh Puasa, Penerjemah Banilah Lubis. Jakarta: Raja Grafindo Persada.

Saurah, A. 'Isa M. bin 'Isa bin. (n.d.). Sunan at-Turmudzi (Juz II). t.tp: Dar al-Fikr.
Syarifuddin, A. (2003). Garis-Garis Besar Fiqh. Bogor: Kencana.

Yunus, M. (1989). Kamus Arab Indonesia. Jakarta: Hida Karya Agung.

Zuhaily, W. (1989). Al-Fiqh al-Islamy wa Adillatuhu (Juz II). Libanon: Dar alFikr. 